\title{
Hysteresis in Hole-free Perovskite Solar Cells with Carbon Counter Electrode Doped Reduced Graphene Oxide (RGO)
}

\author{
Mohammed Basheer1*, Moataz Soliman2, Shakir Ibrahim2, Khalid Gasmalla 2, and Wessam Abdel Salam1. \\ 1AASTMT, College of Engineering and Technology, Electronics and Communications Department, Alexandria, Egypt. \\ 2 IGSR, ALEXANDRIA UNIVERSITY, Materials Science Department, Alexandria, Egypt.
}

\begin{abstract}
Perovskite solar cells achieved high efficiencies but they suffer from the hysteresis of $(\mathrm{J}-\mathrm{V})$ curve that depends on the scan direction. The architecture introduced in this paper is hole free cell with Reduced Graphene Oxide (RGO) as a dopant. The good electrical and optical properties of (RGO) make it acts as a hole transfer layer (HTL) beside its basic role as a dopant of carbon counter electrode. For different areas, the hysteresis decreases by decreasing the cell area. The $\mathrm{TiO} 2 / \mathrm{CH} 3 \mathrm{NH} 3 \mathrm{PbI} 3-\mathrm{xClx}$ interface is truly responsible for the hysteresis in the Perovskite solar cells due to the dependence of the porosity from area to other.
\end{abstract}

\section{Introduction}

In recent few years, perovskite solar cells based on $\mathrm{CH}_{3} \mathrm{NH}_{3} \mathrm{PbI}_{3}$ and $\mathrm{CH}_{3} \mathrm{NH}_{3} \mathrm{PbI}_{3-\mathrm{x}} \mathrm{Cl}_{\mathrm{x}}$ have attracted researchers due to their unique properties such as high light absorbance and high power conversion efficiency (PCE) [1]. The first use of $\mathrm{CH}_{3} \mathrm{NH}_{3} \mathrm{PbI}_{3}$ as a sensitizer in solar cells was in 2009 [2], PCE of perovskite solar cells has risen from $3.8 \%[3,4]$ to more than $22.3 \%$ [5] within eight years. Although the high PCE, anomalous hysteresis appeared in $(\mathrm{J}-\mathrm{V})$ curve which made a problem on the cell stability. Hysteresis in perovskite solar cells depends on a lot of factors such as: cell structure, methods of fabrication, measurements methods, capacitive effect [6], and the effect of illumination, temperature and humidity [7]. The reverse scan (from the open circuit to the short circuit current) always shows higher PCE compared to that of forward scan (from short circuit to the open circuit) which introduces the undesirable hysteresis.[8]. The origin of hysteresis has been discussed on the intrinsic properties such as ferroelectric polarization [9], ionic migration [10], the charge trapping/detrapping caused by the lattice mismatch or voids at this interface which act as capacitors.

In this paper to discuss the relation between the cell area and the hysteresis we used (RGO) [11] as a dopant of carbon counter electrode to enhance its conductivity, moisture impermeability and photoelectric properties. This leads to favorable physical properties, more charge separation and extraction. Hysteresis is usually small for C-PSCs because the thick $\mathrm{TiO}_{2}$ scaffold may eliminate charge accumulation at the $\mathrm{TiO}_{2} /$ perovskite interface.[12] .

\section{Experimental Works}

The perovskite solar cell (PSC) was fabricated by multiple layers; each layer was prepared individually as follows:

\section{1 preparation and deposition of blocking layer.}

Each pre-cleaned FTO substrate was coated with a 60$\mathrm{nm} \mathrm{TiO}_{2}$ by spinning a sol-gel solution $(0.25 \mathrm{M}$ Titanium Isopropoxide in Ethanol) at $2000 \mathrm{rpm}$. The layer was dried at $100{ }^{\circ} \mathrm{C}$ for 10 minutes and then annealed at 500 ${ }^{\circ} \mathrm{C}$ for $30 \mathrm{~min}$ to allow sufficient crystallization in ambient air.

\subsection{Preparation and deposition of mesoporous $\mathrm{TiO}_{2}$} paste.

This layer fabricated as reported in [13] but it was deposited by spin-coating method at $5000 \mathrm{rpm}$, the layer was dried at $100{ }^{\circ} \mathrm{C}$ for 10 minutes and annealed at 450 ${ }^{\circ} \mathrm{C}$. The morphology of the mesoporous $\mathrm{TiO}_{2}$ is shown in Figure.1.

\footnotetext{
* $\overline{\text { Corresponding author: besheersaleh } @ \text { aast.edu }}$
} 


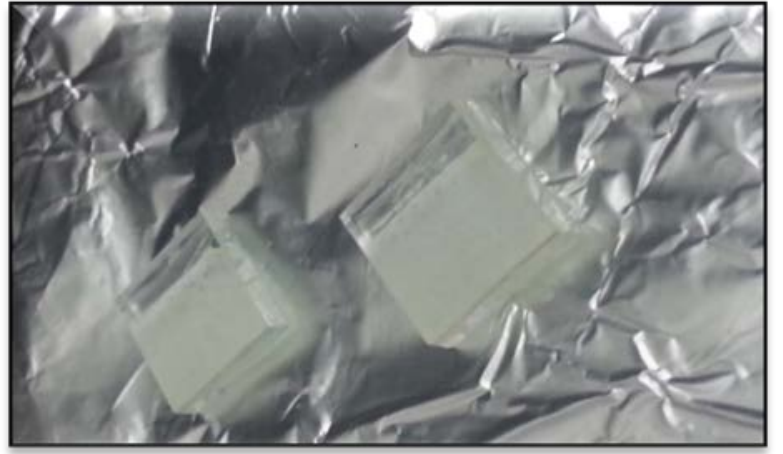

Fig.1. Morphology of mesoporous titanium dioxide $\left(\mathrm{TiO}_{2}\right)$ layer after annealing at $450{ }^{\circ} \mathrm{C}$

\subsection{Preparation of Carbon paste doped RGO.}

One gram of graphite powder, 0.2 gram of carbon black powder , 0.1 gram of reduced graphene oxide (RGO), and 0.1 gram of zirconium dioxide $\left(\mathrm{ZrO}_{2}\right)$ were added into 2 gram $\alpha$-terpineol under continual stirring for 30 min and then 1.5 gram of ethyl cellulose solution in ethanol $(10 \mathrm{wt} \%)$ was added into the mixture. The mixture was agitated with a magnetic stir bar for $10 \mathrm{~min}$. Finally, the mixture was stirred vigorously using ball milling for $5 \mathrm{~h}$ to get the carbon paste. The normal carbon paste was prepared according to the same procedures as this paste without the addition of RGO. The prepared carbon paste as shown in figure 2 was deposited on the top of the $\mathrm{TiO}_{2}$ film by the doctorblading technique, followed by heat-treatment at $500{ }^{\circ} \mathrm{C}$ for $30 \mathrm{~min}$.

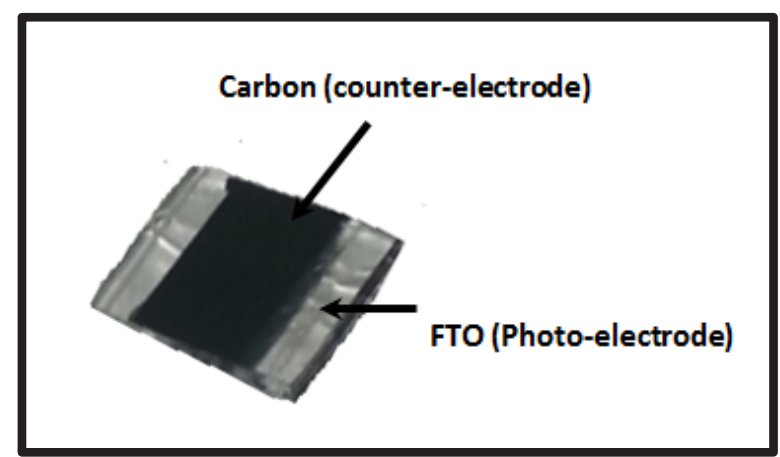

Fig.2. A typical cell with RGO counter electrode layer

\subsection{Preparation and Infiltration of Perovskite.}

$\mathrm{CH}_{3} \mathrm{NH}_{3} \mathrm{PbI}_{3-\mathrm{x}} \mathrm{Cl}_{\mathrm{x}}$ was synthesized using infiltration method and deposited using spin-coating technique. For the synthesis, $100 \mu \mathrm{L}$ of precursor solution was prepared by adding $0.5 \mathrm{~mL}$ of anhydrous dimethyl formamide (DMF) and $0.5 \mathrm{~mL}$ of dimethyl sulfoxide (DMSO) into a mixture of $\mathrm{CH}_{3} \mathrm{NH}_{3} \mathrm{I}(0.423 \mathrm{~g})$ and $\mathrm{PbCl}_{2}(0.246 \mathrm{~g})$. The Perovskite layer has been infiltrated in the mesoprous carbon electrode and then spin-coated as shown in figure 3 inside the glove box at different spin rates (from 1000 -
2000 and $2500 \mathrm{rpm}$.) for $60 \mathrm{~s}$. Then, the films were annealed on a hot plate for 30 minutes at $100{ }^{\circ} \mathrm{C}$.

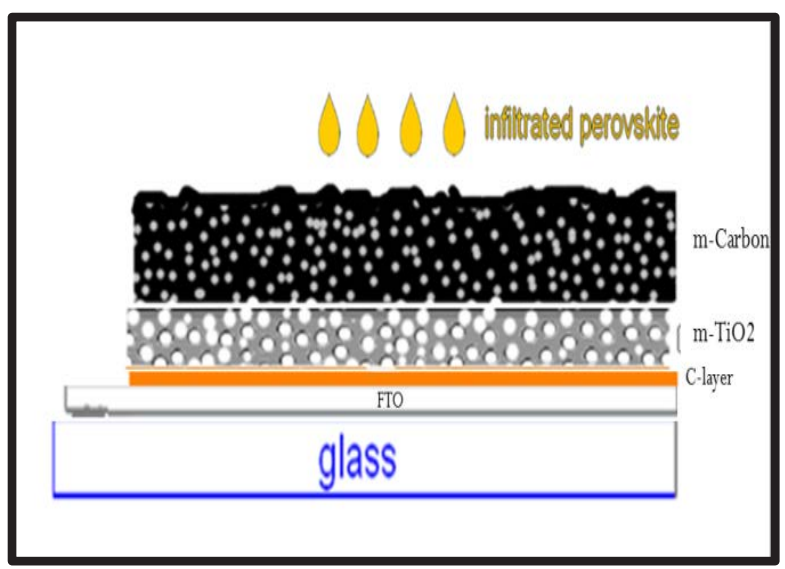

Fig.3. A hole-free perovskite solar cell architecture .

\section{Perovskite and Cell characterizations}

After the cell fabrication, the cell characterized by exposing a solar cell to a standard light source(xenon lamp) (typically air mass (1.5 AM), and power of 100 $\mathrm{mWcm}^{-2}$ ) and sweeping by applying predetermined biasing voltage range across the terminals of the cell and the current is measured by [kiethely 2635A ]. Different parameters ,namely, open circuit voltage $\left(\mathrm{V}_{\mathrm{oc}}\right)$, short circuit current density $\left(\mathrm{J}_{\mathrm{sc}}\right)$, fill factor(FF), power conversion efficiency (PCE) and hysteresis index(HI) are listed in table 1 for different cell areas and different scanning directions(forward-reverse) .The hysteresis index is calculated by[14]:

$$
H I=\frac{J_{R S}\left(0.8 V_{o c}\right)-J_{F S}\left(0.8 V_{o c}\right)}{J_{R S}\left(0.8 V_{o c}\right)}
$$

Where: $\mathrm{J}_{\mathrm{RS}}$ is the current density in reverse direction, $\mathrm{J}_{\mathrm{FS}}$ is the current density in forward direction.

To examine the surface morphology of the perovskite alone we have used scanning electron microscope (JSM6360). The structure and phases of the materials are examined byX-ray Diffraction (schimadzu-7000)[11].the absorption and estimated band gap of the perovskite $\left(\mathrm{Ch}_{3} \mathrm{NH}_{3} \mathrm{PbI}_{3-\mathrm{x}} \mathrm{Cl}_{\mathrm{x}}\right)$ was measured using UVVisible spectroscopy (EVO300 PC) as shown in next figures(4-6), the absorption peak at the wavelength of around $750 \mathrm{~nm}$ of $\mathrm{CH} 3 \mathrm{NH} 3 \mathrm{PbI}_{3-\mathrm{x}} \mathrm{Cl}_{\mathrm{x}}$ film was observed as shown in figure (6). Perovskite film exhibits very strong absorption intensity [15]. 


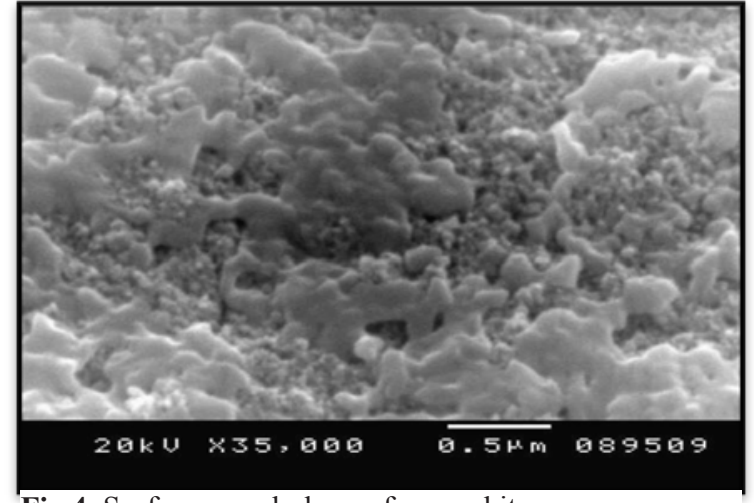

Fig.4. Surface morphology of perovskite.
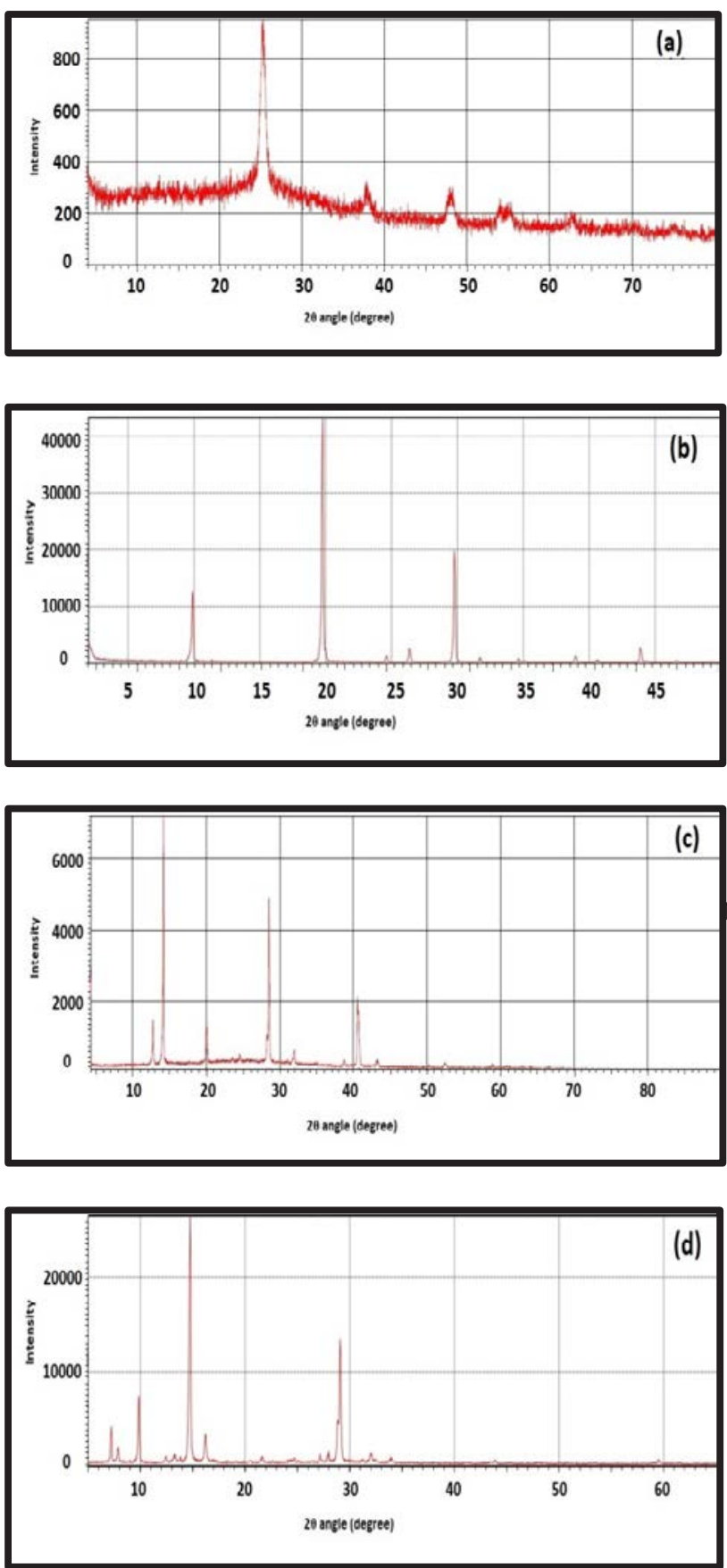

Fig.5. XRD of : a.TiO ${ }_{2}$, b. MAI, c. $\mathrm{MAPbI}_{3}$ d. $\mathrm{MAPbI}_{3-\mathrm{x}} \mathrm{Clx}$

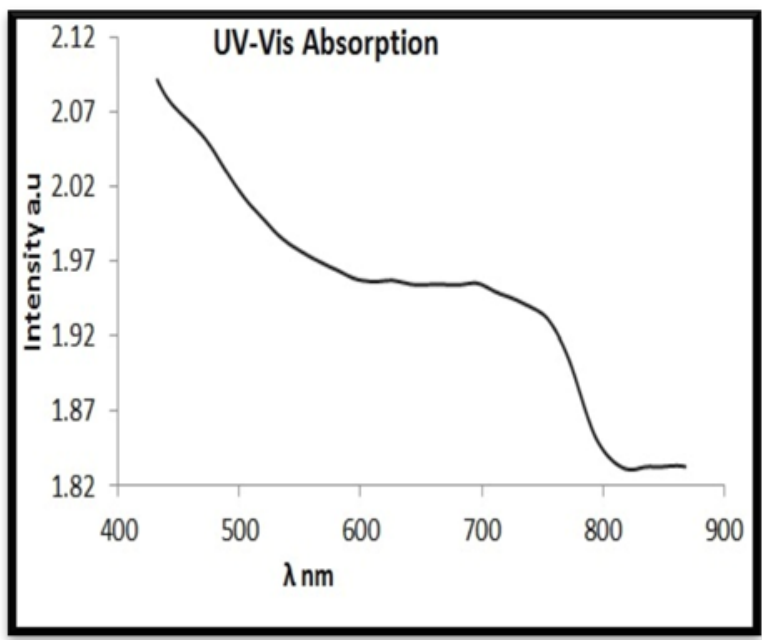

Fig.6. UV-Visible absorption spectrum of $\mathrm{Ch}_{3} \mathrm{NH}_{3} \mathrm{PbI}_{3-\mathrm{x}} \mathrm{Cl}_{\mathrm{x}}$

\section{Results}

After measuring the $(\mathrm{J}-\mathrm{V})$ curve, the results shown in table 1:

\begin{tabular}{|l|l|l|l|l|l|l|}
\hline $\begin{array}{l}\text { Cell } \\
\text { area } \\
\left(\mathbf{c m}^{2}\right)\end{array}$ & $\begin{array}{l}\text { Scan } \\
\text { direction }\end{array}$ & $\frac{\Delta \mathbf{V o c}_{\%}}{V o c}$ & $\frac{\Delta \mathbf{J s c}_{0}}{J S C}$ & $\frac{\Delta \mathbf{F F}}{F F} \%$ & $\eta \%$ & $\mathrm{HI}$ \\
\hline $\mathbf{0 . 1 6}$ & REVERSE & +16.5 & -65.5 & +25.2 & 0.96 & 0.13 \\
\hline $\mathbf{0 . 1 8}$ & REVERSE & +31.6 & -55 & +24.6 & 0.67 & 0.14 \\
& FORWARD & +5.2 & -57 & +7.5 & 0.54 & \\
\hline $\mathbf{0 . 2 0}$ & REVERSE & 0 & -50 & +28.8 & 0.76 & 0.22 \\
& FORWARD & +17.5 & -34 & +19.5 & 0.28 & \\
\hline
\end{tabular}

Table 1 Reduction in photovoltaic parameters due to Hysteresis.

From the table we found that as the cell area increases, the hysteresis index (HI) increases which means that the main reason for the hysteresis occurrence comes from the perovskite layer interfaces .The hysteresis less than for cells containing hole transporting layers (HTL) with Perovskite layer as reported with planar structure [16] . The measurement protocol used is voltage sweeping with scan rate $0.3 \mathrm{mv} / \mathrm{sec}$ which is very slow if the scan rate increased to be $0.3 \mathrm{v} / \mathrm{sec}$, it also may reduce the hysteresis index. 


\section{Conclusion}

For the hole - free Perovskite solar cell structure, the hysteresis decreases with the absence of the interface perovskite/HTL .Additionally, when the area decreases, the hysteresis decreases. This ensures that the area of the interface between perovskite $/ \mathrm{TiO}_{2}$ should be small to reduce the trapping /detrapping of charges.

This research was supported by Arab Academy for Science ,Technology and Maritime Transport(AASTMT).We thank Gehan (Technical Engineer, Institute of Graduate studies and research(IGSR) laboratory) for helping in cells fabrication and characterization .We thank Sherif Abdullah(teaching assistance, college of Engineering and Technology ,Electronics and Communications department,AASTMT) for his comments that helped in improving this paper research.

\section{References}

1-Jung, Hyun Suk, and Nam.Gyu Park. Perovskite solar cells: from materials to devices, Materials views small 11.1, 10-25, (2015).

2- Kojima, A., Teshima, K., Shirai, Y., \& Miyasaka, T. Organometal halide perovskites as visible-light sensitizers for photovoltaic cells. Journal of the American Chemical Society, 131(17), 6050-6051. (2009).

3-- Lee, M. M., Teuscher, J., Miyasaka, T., Murakami, T. N., \& Snaith, H. J. Efficient hybrid solar cells based on mesosuperstructured organometal halide perovskites. Science, 1228604. (2012).

4- Kim, H. S., Lee, C. R., Im, J. H., Lee, K. B., Moehl, T., Marchioro, A., ... \& Grätzel, M . Lead iodide perovskite sensitized all-solid-state submicron thin film mesoscopic solar cell with efficiency exceeding 9\%. Scientific reports, 2, 591, (2012).

5-Tianyue Wang, Jiewei Chen, Gaoxiang Wu and Meicheng Li. Optimal design of efficient hole transporting layer freeplanar perovskite solar cell, Sci China Mater 59(9): 703709 (2016).

6-Snaith, H. J., Abate, A., Ball, J. M., Eperon, G. E., Leijtens, T., Noel, N. K., ... \& Zhang, W. Anomalous hysteresis in perovskite solar cells. The journal of physical chemistry letters, 5(9), 1511-1515, (2014)

7-Dae Ho Song1, Min Hyeok Jang1, Min Ho Lee1, Jin Hyuck Heo1,Jin Kyoung Park1, Shi-Joon Sung2, Dae-Hwan Kim2, $\mathrm{Ki}-\mathrm{Ha}$ Hong3 and Sang Hyuk Im1. A discussion on the origin and solutions of hysteresis in perovskite hybrid solar cells, $J$. Phys. D: Appl. Phys. 49473001 (11pp) (2016).

8- Ajay Kumar Jena and Tsutomu Miyasaka. Hysteresis Characteristics and Device Stability, Organic-Inorganic Halide Perovskite Photovoltaics, ISBN 978-3-319-35112-4(2016).
9- Wei, J., Zhao, Y., Li, H., Li, G., Pan, J., Xu, D., ... \& Yu, D. Hysteresis analysis based on the ferroelectric effect in hybrid perovskite solar cells. The journal of physical chemistry letters, 5(21), 3937-3945, (2014).

10- Tress, W., Marinova, N., Moehl, T., Zakeeruddin, S. M., Nazeeruddin, M. K., \& Grätzel, M. Understanding the ratedependent $J-V$ hysteresis, slow time component, and aging in $\mathrm{CH}{ }_{3} \mathrm{NH}{ }_{3} \mathrm{PbI}{ }_{3}$ perovskite solar cells: the role of a compensated electric field. Energy \& Environmental Science, 8(3), 995-1004, (2015).

11- Chen, Haining, and Shihe Yang. Carbon-Based Perovskite Solar Cells without Hole Transport Materials: The Front Runner to the Market. Advanced Materials (2017).

12-Ito, S., Murakami, T. N., Comte, P., Liska, P., Grätzel, C., Nazeeruddin, M. K., \& Grätzel, M. Fabrication of thin film dye sensitized solar cells with solar to electric power conversion efficiency over 10\%. Thin solid films, 516(14), 4613-4619, (2008).

13-Kim, H. S., \& Park, N. G. Parameters affecting I-V hysteresis of $\mathrm{CH} 3 \mathrm{NH} 3 \mathrm{PbI} 3$ perovskite solar cells: effects of perovskite crystal size and mesoporous TiO2 layer. The journal of physical chemistry letters, 5(17), 2927-2934, (2014).

14- Song, Z., Watthage, S. C., Phillips, A. B., Tompkins, B. L., Ellingson, R. J., \& Heben, M. J. Impact of processing temperature and composition on the formation of methylammonium lead iodide perovskites. Chemistry of Materials, 27(13), 4612-4619, (2015).

15- Li, H., Yang, Y., Feng, X., Shen, K., Li, H., Li, J., ... \& Song, F. Performance improvement of $\mathrm{CH} 3 \mathrm{NH} 3 \mathrm{PbI} 3$ perovskite solar cell by CH3SH doping. Nanomaterials and Nanotechnology, 6, 24, (2016).

16-Cojocaru, L., Uchida, S., Jayaweera, P. V., Kaneko, S., Nakazaki, J., Kubo, T., \& Segawa, H. Origin of the Hysteresis in I-V Curves for Planar Structure Perovskite Solar Cells Rationalized with a Surface Boundary-induced Capacitance Model. Chemistry Letters, 44(12), 1750-1752, (2015). 